Original Article

\title{
Assessment of carbamazepine acute toxicity in the cockle Cerastoderma edule through chemical, physiological and biochemical tools
}

\author{
Avaliação da toxicidade aguda da carbamazepina no berbigão Cerastoderma edule por \\ meio de ferramentas químicas, fisiológicas e bioquímicas
}

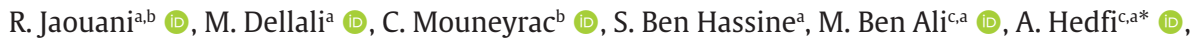 \\ M. M. Hassan ${ }^{\text {c,d }}$ (D) H. Beyremª ${ }^{\text {(D) }}$ and F. Boufahja ${ }^{\mathrm{a}}$ (D) \\ aUniversity of Carthage, Laboratory of Biomonitoring of the Environment LR01 ES14, Faculty of Sciences of Bizerte, Zarzouna 7021, Tunisia \\ 'Laboratory 'Sea, Molecules, Health', Catholic University of the West, Angers, France \\ 'Department of Biology, College of Sciences, Taif University, P.O. Box 11099, Taif, 21944, Saudi Arabia \\ dZoology Department, Faculty of Science, Ain Shams University, 11566, Cairo, Egypt
}

\begin{abstract}
The cockle Cerastoderma edule was exposed to four concentrations $\left(5,10,20\right.$ and $\left.70 \mu \mathrm{g} \mathrm{L}^{-1}\right)$ of carbamazepine (CBZ). This anticonvulsant was found to alter the mussel behavior of by reducing its clearance rate (CR). Analysis of CBZ accumulation in tissues of $C$. edule was carried out using HPLC-UV after 48 or 96 hours of exposure. In addition, an overproduction of $\mathrm{H}_{2} \mathrm{O}_{2}$ by the bivalves was detected following exposure to $\mathrm{CBZ}$ but nitrite levels remained unchanged. Moreover, superoxide dismutase and catalase activities showed a significant increase in relation to their contact with CBZ. The activity of the biotransformation enzyme gluthatione-S-transferase did not change during exposure. Malondialdehyde (MDA) levels indicating cellular damage, increased when bivalves were exposed to 20 and $70 \mu \mathrm{g} \mathrm{l}^{-1}$ of carbamazepine for $96 \mathrm{~h} \mathrm{CBZ}$. The results also indicate that acetylcholinesterase activity (AChE) was inhibited in all CBZ concentrations during the $48 \mathrm{~h}$ exposure period. However, during the $96 \mathrm{~h}$ exposure period, AChE was only inhibited at the highest concentration. Further studies are needed now for more exploration of the toxicity of CBZ since it could be bioaccumulable throughout the food web and may affect non-target organisms.

Keywords: Carbamazepine, Cerastoderma edule, acute toxicity, Clearance rate, biomarkers.

Resumo

O berbigão Cerastoderma edule foi exposto a quatro concentrações $(5,10,20$ e $70 \mu \mathrm{g}$ L-1) de carbamazepina (CBZ). Este anticonvulsivante alterou o comportamento do mexilhão, reduzindo sua taxa de depuração (CR). A análise do acúmulo de CBZ nos tecidos de C. edule foi realizada por HPLC-UV após 48 ou 96 horas de exposição. Além disso, uma superprodução de $\mathrm{H}_{2} \mathrm{O}_{2}$ pelos bivalves foi detectada após a exposição à $\mathrm{CBZ}$, mas os níveis de nitrito permaneceram inalterados. Além disso, as atividades de superóxido dismutase e catalase apresentaram aumento significativo em relação ao contato com CBZ. A atividade da enzima de biotransformação glutationa-S-transferase não se alterou durante a exposição. Os níveis de malondialdeído (MDA), indicando dano celular, aumentaram quando os bivalves foram expostos a 20 e $70 \mu \mathrm{g}$ l-1 de carbamazepina por $96 \mathrm{~h} \mathrm{CBZ}$. Os resultados também indicam que a atividade da acetilcolinesterase (AChE) foi inibida em todas as concentrações de CBZ durante o período de exposição de 48 horas. No entanto, durante o período de exposição de 96 horas, a AChE foi inibida apenas na concentração mais alta. Mais estudos são necessários agora para uma maior exploração da toxicidade da CBZ, uma vez que pode ser bioacumulável em toda a cadeia alimentar e pode afetar organismos não alvo.
\end{abstract}

Palavras-chave: Carbamazepina, Cerastoderma edule, toxicidade aguda, taxa de liberação, biomarcadores.

\section{Introduction}

A large variety of contaminants (e.g., industrial additives, pharmaceuticals, personal care products, steroids) have been identified in wastewater and surface waters (Noguera-Oviedo and Aga, 2016). Pharmaceuticals and their metabolites can reach water bodies through

effluents from wastewater treatment plants (WWTPs), sewage systems, industrial discharge, aquaculture, and agriculture (Sui et al., 2015). These drugs are not completely removed by WWTPs and, after the effluent is discharged into the wider environment, they may have direct effects

*e-mail: o.zaied@tu.edu.sa

Received: December 28, 2020 - Accepted: February 11, 2021 
on numerous species and ecosystems (Sui et al., 2015). Drugs could also harmful to non-target biota, especially filter-feeding taxa, as they are continuously exposed to micropollutants into the ecosystem (Santos et al., 2010). Fortunately, recent progress in analytical techniques has allowed a more accurate identification and quantification of these molecules in water, soil, and biota.

Pharmaceuticals have been considered as contaminants of emerging concern during the last twenty or more years. Carbamazepine (CBZ) is primarily used in human medicine in the treatment of epilepsy with an annual consumption rate of about 2,235,000 pounds worldwide (Zhang et al. 2008). It acts physiologically to stabilize the inactivated state of sodium channels, thereby rendering brain cells less excitable (Contardo-Jara et al., 2011). For these reasons, CBZ is a drug commonly found in aquatic areas (Khazri et al., 2019a). Concentrations of 60.58, 93.19, and $132 \mu \mathrm{g} \mathrm{l}^{-1}$ were recorded in wastewater collected from northern Tunisia (Khazri et al., 2019a). In other countries (Germany, China, Spain, Belgium, The Netherlands, and France), concentrations ranged from 0.03 to $11.6 \mathrm{~g} \mathrm{~g} \mathrm{l}^{-1}$ in wastewater effluents, surface and ground waters (Liu et al., 2015; Huerta-Fontela et al., 2011).

According to Martin-Diaz et al. (2009), CBZ was resistant to biodegradation even the measured concentrations were low. CBZ exhibits extremely slow photodegradation and its ubiquitous distribution in aquatic areas. Numerous studies have focused on its effects on non-target organisms such as soil microorganisms, insects, fish, birds, and various bivalve species (Ruditapes decussatus Linnaeus, 1758, Mytilus galloprovincialis Lamarck, 1819) (Clara et al., 2004). It has been found that exposure to $\mathrm{CBZ}$ induces oxidative stress, immunotoxicity, cytotoxicity, and alteration of metabolism and health status of organisms (Gagné et al., 2006; Contardo-Jara et al., 2011; Aguirre-Martínez et al., 2013; Tsiaka et al., 2013).

Filter feeders are also the most used marine organisms as indicators due to their tolerance and potential transport of pollutants through the food chain (Dellali et al., 2001). The cockle Cerastoderma edule Linnaeus, 1758 has been used as an indicator species in environmental health status assessments due to its large filtration capacity, sessile habit, wide geographical distribution, easy handling and collection, and its sensitivity to various pollutants (Paul-Pont et al., 2010). In addition, C. edule is a species of commercial and economic interests around the Mediterranean Sea, due to its abundance and the quality of the flesh (De Montaudouin et al., 2010). It is also relatively tolerant to different classes of pollutants and environmental stressors, making it suitable for marine biomonitoring and bioassays (Dellali et al., 2001).

The Ghar El Melh Lagoon is situated in northeastern Tunisia and is directly connected to the Mediterranean Sea. It is a multi-contaminated site because it is the watershed of several rivers, including the Oued Medjerda, and receives various types of household and industrial effluent (Mahmoudi et al., 2002). This has led to a progressive deterioration in biodiversity in this ecosystem (Guasmi et al., 2006). Cerastoderma edule is an abundant and typical bivalve species in this lagoon.
In this work, the choice of $\mathrm{CBZ}$ concentrations was based on previously reported CBZ levels in different aquatic ecosystems in Tunisia and across the globe (Khazri et al., 2019a; Oliveira et al., 2017). For example, Khazri et al. (2019a) founded a CBZ concentration of $60.58 \mu \mathrm{g} \mathrm{l}^{-1}$ in effluent samples from a WWTP in Bizerte (Tunisia). The aim of this study was to investigate the possible effects of the environmentally relevant concentrations of CBZ ranging from $5 \mu \mathrm{g} \mathrm{l}^{-1}$ to $70 \mu \mathrm{g} \mathrm{l}^{-1}$ on the cockle $C$. edule. First, we evaluated the ability of the cockle to accumulate CBZ. Consequently, this bivalve would provide the scientific community an effective and timely indicator of the probable risks deriving from the consumption of contaminated seafood from coastal countries where CBZ is recommended and used as treatment of epilepsy. Second, we assessed the possible toxicity of CBZ through different biochemical biomarkers of exposure and effect. In details, we investigated the effects of $\mathrm{CBZ}$ on bivalves ( $C$. edule) in the laboratory by using a multi-biomarker approach (Khazri et al., 2018; Oliveira et al., 2017; Almeida et al., 2015). The intensity of oxidative stress was measured after evaluating levels of the reactive- (ROS) and nitrous(NOS) oxygen species produced, and the activities of enzymes of defense and those related to lipid peroxidation. Neurotoxicity and respiratory capacity were also measured by quantifying acetylcholinesterase activity (AChE) and clearance rate (CR), respectively.

\section{Material and Methods}

\subsection{Acclimation in the laboratory}

Specimens of $C$. edule (shell length: $2.48 \pm 0.28 \mathrm{~cm}$, shell width: $2.5 \pm 0.48 \mathrm{~cm}$ ) were collected on February 4, 2017 from Ghar El Melh lagoon ( $37^{\circ} 8^{\prime} 36.73^{\prime \prime} \mathrm{N}$ and $10^{\circ} 12^{\prime} 38.66^{\prime \prime} \mathrm{E}$ ), Tunisia. After transportation to the laboratory, the specimens were placed in tanks of $2 \mathrm{~L}$ (five bivalves per tank) for a week under a photoperiod regime of $16 \mathrm{~h}$ light:8 h darkness. Each tank contained $2 \mathrm{~L}$ of natural filtered seawater from the Bay of Bizerte (Tunisia). The media was renewed every two days during the acclimatization with a continuous aeration. The exposure design was selected based on previous published studies (Khazri et al., 2016; Sellami et al., 2017). The laboratory temperature was maintained at $19^{\circ} \mathrm{C}$ (field temperature) and the water temperature was maintained at $17^{\circ} \mathrm{C}$, and pH was 8.7 (Khazri et al., 2017). Measurements were conducted by means of a temperature/conductivity meter (WTW LF 196, Weilheim, Germany), and pH meter (WTW, model pH 330/SET-1).

The tank water was replaced on a daily basis to feed the specimens with the nutrients present in natural seawater from the Bay of Bizerte (Salhi et al., 2018) and, also, to avoid accumulation of organic matter and the possible appearance of nitrogen compounds such as ammonium, nitrite or nitrate in the tanks. An absence of mortality was observed throughout the experiment and all bivalves fed normally.

\subsection{Bioassay}

A CBZ concentration range was selected based on concentrations previously measured in WWTPs from 
northern Tunisia (Khazri et al., 2019a). Following the acclimation period, five treatments: (1) control (natural seawater only), (2) CBZ: $5 \mu \mathrm{g} \mathrm{l}^{-1}$, (3) CBZ: $10 \mu \mathrm{g} \mathrm{l}^{-1}$, (4) CBZ: $20 \mu \mathrm{g} \mathrm{l}^{-1}$, and (5) CBZ: $70 \mu \mathrm{g} \mathrm{l}^{-1}$ were established in a triplicate design (three tanks per treatment, five individuals per tank) and maintained for two exposure periods, 48 and $96 \mathrm{~h}$. In this study, only the acute toxicity of CBZ was targeted for evaluation which explain that the experiment was ended after these two time slots. Tank water was not replaced during both exposure periods. Water parameters were maintained as follows: temperature $=17^{\circ} \mathrm{C}, \mathrm{pH}=8$, and salinity $=32$ PSU. No mortalities were observed in either exposure period.

\subsection{Quantification of carbamazepine}

Three replicates of water $(200 \mathrm{ml})$ were sampled from the control and CBZ microcosms, and analytical samples were taken by SPE using C18 cartridges (OASIS HLB) purchased from Waters (Milford,MA). These steps were followed by an elution with of methanol $\geq 99.9 \%$ (CAS No. 67-56-1) (6 ml). At the end, an evaporation of these extracts was applied, followed by a reconstitution in methanol ( $1 \mathrm{ml}$ ) as described by Khazri et al. (2019b).

The CBZ concentrations in both extracts from water and tissues of $C$. edule were quantified at $285 \mathrm{~nm}$ by high performance liquid chromatography (Agilent 1100 series HPLC system) equipped with a reversed-phase $\mathrm{C} 18$ column ( $5 \mu \mathrm{m}, 4.6 \times 250 \mathrm{~mm}$ ), a quaternary pump, an auto sampler, and a UV detector. A mixture of 70:30 (v:v) methanol and

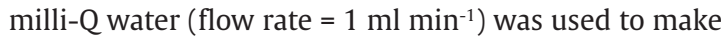
up the mobile phase. All samples and standards were analyzed in triplicate.

\subsection{Clearance Rate (CR)}

The CR was evaluated by measuring the neutral red dyed particles lost from the water column (Coughlan, 1969). At the end of all exposure phases, specimens were taken from each treatment applied $(n=4)$ and put in $200 \mathrm{ml}$ of neutral red dye $\left(1 \mathrm{mg} \mathrm{l}^{-1}\right)$ following the rule of one clam per beaker (CAS No. 553-24-2) purchased from SLIM LAB Tunisia. In this work, CR was only measured after

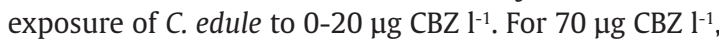
this parameter was not considered because it is very high compared to environmentally concentrations.

\subsection{Biomarker measurements}

All biomarker quantification procedures were carried out at temperatures between 0 and $4{ }^{\circ} \mathrm{C}$. First of all, the soft tissues were homogenized by using an Ultra Turrax disperser (model IKA T18 Basic) in $\mathrm{K}_{3} \mathrm{PO}_{4}$ buffer $(\mathrm{pH} 7.4$, $0.1 \mathrm{mM})$. The result was then centrifuged $\left(9000 \mathrm{rpm}, 4^{\circ} \mathrm{C}\right.$, $30 \mathrm{~min}$ ) and the protein content in each supernatant was estimated using the Bradford method (Bradford, 1976).

As reported Ellman et al. (1961), the acetylcholinesterase activity (AChE) was determined in nMol min ${ }^{-1} \mathrm{mg}^{-1}$ protein after measuring the absorbance ( $412 \mathrm{~nm}, 5 \mathrm{~min}$ ) in presence of $1 \mathrm{mM}$ acetylthiocholine. The evaluation of SOD activity ( $\mathrm{U} \mathrm{mg}^{-1}$ protein) followed the indirect method (i.e. the epinephrine/adenochrome system) according to Misra and Fridovich (1972). According to Aebi (1974), CAT activity can be determined by using the spectrophotometric method which measures absorbance at $240 \mathrm{~nm}$ during the degradation of hydrogen peroxide $\left(\mathrm{H}_{2} \mathrm{O}_{2}\right)$. The CAT activity was given in $\mathrm{nmol} \mathrm{min}^{-1} \mathrm{mg}^{-1}$ protein. The measurement of this molecule was made using a spectrophotometer with an absorbance of $546 \mathrm{~nm}$.

Hydrogen peroxide $\left(\mathrm{H}_{2} \mathrm{O}_{2}\right)$ concentrations were measured according to methods described by Kakinuma et al. (1979) and Green et al. (1982) using an adapted kit (Biomagreb, Tunisia). Glutathione-S-Transferase (GST) activity was spectrophotometrically evaluated (at $340 \mathrm{~nm}$, $\varepsilon=9.6 \mathrm{Mm} \mathrm{cm}^{-1}$ ). Thus, the production of 1-glutathion2,4-dinitrobenzene was followed as proposed Habig et al. (1974). This compound comes from the conjugation of 1-chloro-2,4-dinitrobenzene (CDNB) with a glutathione reduced form (GSH).

Lipid peroxidation (LPO) was determined through quantifying malondialdehyde (MDA) which is a lipid peroxidation product (Draper and Hadley, 1990). The absorbance was measured at $535 \mathrm{~nm}\left(\varepsilon=156 \mathrm{Mm} \mathrm{cm}^{-1}\right)$. At the end, the LPO levels were given as the MDA produced in $\mathrm{nMol} \mathrm{min} \mathrm{mg}^{-1} \mathrm{mg}^{-1}$ protein.

\subsection{Statistical processing}

Data, given in mean \pm standard deviation (SD), were first integrated into STATISTICA v8. Bartlett, Levene and Brown-Forsythe tests were used to check parametric test criteria, normality and variance homogeneity, respectively. Thereafter, two parametric tests, one-way analysis of variance (ANOVA) and Tukey HSD, were applied to detect significant differences in multiple comparisons between the controls and different treatments.

\section{Results}

\subsection{Chemical analysis}

CBZ was not detected in water samples originating from Ghar El Melh lagoon where the $C$. edule specimens were collected. There were no changes in CBZ concentrations in any tank water between the beginning and the end of all treatments (one control and four CBZ exposure levels, 48 and $96 \mathrm{~h}$ time periods) (Table 1 ). After $48 \mathrm{~h}$, all the soft tissues of $C$. edule specimens exposed to $10 \mu \mathrm{g} \mathrm{CBZ}^{-1}$ contained CBZ (Table 1).

\subsection{Clearance rate}

The results obtained for the CR are shown in Figure 1. A high CR was observed during the first $30 \mathrm{~min}$ of the experiment for specimens exposed to 10 and $20 \mu \mathrm{g} \mathrm{l}^{-1}$ of CBZ. It was clearly noted that 1.5 and 2 hours of exposure were followed by a discernible decline of the $C R$ values for mussels collected from treatments 5, 10, and $20 \mu \mathrm{g} \mathrm{CBZ}^{-1}$.

\subsection{Neurotoxicity}

The AChE activity results for specimens exposed to CBZ for 48 or $96 \mathrm{~h}$ are presented in Figures $2 \mathrm{~A}$ and 2B, respectively. Following 48 h of exposure, AChE activity significantly decreased in all CBZ exposure treatments 
Table 1. Carbamazepine concentrations $\left(5-70 \mu \mathrm{g} \mathrm{l}^{-1}\right)$ in the water phase where Cerastoderma edule were exposed, after $48 \mathrm{~h}$ and $96 \mathrm{~h}$. Values are the mean of 2 samples per concentration $\times 3$ replicates of the HPLC-UV quantification. Same letters indicate no significant differences between measured concentrations after $48 \mathrm{~h}$ and $96 \mathrm{~h}(p<0.05)$.

\begin{tabular}{|c|c|c|c|}
\hline \multirow{2}{*}{ Conditions } & \multirow{2}{*}{ Nominal concentration } & $\begin{array}{l}\text { Measured concentration } \\
\text { (Exposure medium) }\end{array}$ & $\begin{array}{l}\text { Measured concentration } \\
\text { (Exposure medium) }\end{array}$ \\
\hline & & 48 hours & 96 hours \\
\hline Control & 0 & Not detected & Not detected \\
\hline $\mathrm{C} 1\left(\mu \mathrm{g} \mathrm{l}^{-1}\right)$ & 5 & $4.54 \pm 0.40^{(\mathrm{a})}$ & $4.28 \pm 0.88^{(\mathrm{a})}$ \\
\hline $\mathrm{C} 2\left(\mu \mathrm{gl}^{-1}\right)$ & 10 & $9.46 \pm 0.14^{(\mathrm{a})}$ & $9.20 \pm 0.59^{(\mathrm{a})}$ \\
\hline $\mathrm{C} 3\left(\mu \mathrm{g} \mathrm{l}^{-1}\right)$ & 20 & $19.4 \pm 0.11^{(\mathrm{a})}$ & $16.6 \pm 0.24^{(\mathrm{a})}$ \\
\hline $\mathrm{C} 4\left(\mu \mathrm{g} \mathrm{l^{-1 }}\right)$ & 70 & $69.4 \pm 0.35^{(\mathrm{a})}$ & $68.7 \pm 0.67^{\text {(a) }}$ \\
\hline
\end{tabular}

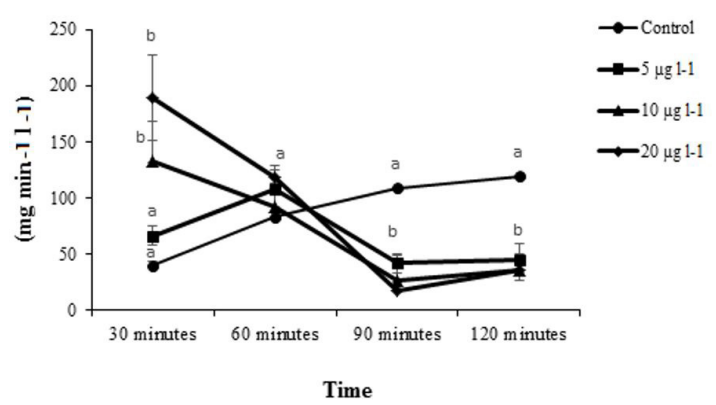

Figure 1. Clearance rate in Cerastoderma edule exposed to three concentrations of $\operatorname{CBZ}\left(5,10,20 \mu \mathrm{g} . \mathrm{L}^{-1}\right)$ during $2 \mathrm{~h}$. Values are the mean of 3 replicates. Letters (a-b) indicate significant differences $(\mathrm{p} \leq 0.05)$ between control and exposure conditions.

compared to the controls. At the end of $96 \mathrm{~h}$ of exposure, only the high concentration $\left(70 \mu \mathrm{g} \mathrm{l}^{-1}\right)$ was associated with a reduced AChE activity.

\subsection{Antioxidant enzymes}

Results of antioxidant enzymes (SOD, CAT) levels measured in C. edule specimens following their laboratory exposure to CBZ for 48 and $96 \mathrm{~h}$ are shown in Figure 2. SOD activity (Figure 2C, D) was induced only specimens located in the $20 \mu \mathrm{g} \mathrm{l}^{-1}$ treatment after $48 \mathrm{~h}$ of exposure. Nevertheless, after $96 \mathrm{~h}$, all treatments considered were followed by a significant enhance in terms of SOD activity. In relation to CAT activity, no significant difference was observed across all treatments, except in the highest exposure treatment $\left(70 \mu \mathrm{g} \mathrm{l}^{-1}\right)$ after $96 \mathrm{~h}$, where it increased significantly compared with the control (Figure 2E, F).

\subsection{Biotransformation enzyme}

No significant changes in GST were detected in any treatment following 48 and $96 \mathrm{~h}$ of exposure (Figures $2 \mathrm{G}, \mathrm{H}$ ).

\subsection{Pro-oxidant}

Following $48 \mathrm{~h}$ of exposure, the level of $\mathrm{H}_{2} \mathrm{O}_{2}$ (Figure $3 \mathrm{~A}$ ) increased significantly from an average of 0.247 ( \pm 0.017 SD) $\mathrm{nmol} \mathrm{mg}{ }^{-1}$ protein in specimens from the lowest exposure treatment $\left(5 \mu \mathrm{g} \mathrm{l}^{-1}\right)$ to an average of $0.312( \pm 0.030 \mathrm{SD}) \mathrm{nmol}$ $\mathrm{mg}^{-1}$ protein in the highest exposure treatment $\left(70 \mu \mathrm{g} \mathrm{l}^{-1}\right)$.
Compared with the controls, these increases correspond to increases of $89.29 \%$ and $136.56 \%$, respectively. Following $96 \mathrm{~h}$ of exposure (Figure 3B), a significant increase was recorded in the level of $\mathrm{H}_{2} \mathrm{O}_{2}$ production in specimens from the highest exposure treatment $\left(70 \mu \mathrm{g} \mathrm{l}^{-1}\right)$. Intracellular $\mathrm{H}_{2} \mathrm{O}_{2}$ (mean $\pm \mathrm{SD}: 0.376 \pm 0.068 \mathrm{nmol}^{-1} \mathrm{mg}^{-1}$ protein) was observed to be three-times higher compared with the control. Nitrate (NO) levels did not vary at any exposure treatment compared to controls whatever was the time slot considered (48 or $96 \mathrm{~h}$ ) (Figures 3C, D).

\subsection{Indicators of cellular damage}

No significant difference in MDA levels were detected between treatments following $48 \mathrm{~h}$ of exposure. However, after $96 \mathrm{~h}$, MDA levels significantly increased in the two highest exposure treatments ( 20 and $70 \mu \mathrm{g} \mathrm{l}^{-1}$ ) compared with the controls (Figures 3E, F).

\section{Discussion}

\subsection{Chemical analysis}

WWTPs generally do not remove all CBZ from wastewater (Almeida et al., 2015). Consequently, CBZ can enter the aquatic environment via treated effluent. Almeida et al. (2015) observed that CBZ was not absorbable by bivalve shells which confirm the obtained results herein. The goal of our work was to evaluate the toxicity of $\mathrm{CBZ}$ on the cockle using various biomarkers involved in neurotoxicity, oxidative stress, and physiological responses following exposure to four CBZ concentrations over 48 and $96 \mathrm{~h}$.

\subsection{Clearance rate}

The presence of CBZ significantly reduced the CR of C. edule specimens. This could be attributed to the fact that $C$. edule animals are protected from predators by a shell, which may offer additional protection from harmful pharmaceuticals such as CBZ (Gosling, 2003). Furthermore, in the presence of $\mathrm{CBZ}$, siphon closure has been observed in the freshwater mussel Corbicula fluminea Muller, 1774 exposed to 5 and $50 \mu^{\mathrm{g} \mathrm{l}^{-1}}$ for 30 days (Chen et al., 2014). Similar to previous findings for the bivalve Sinanodonta 

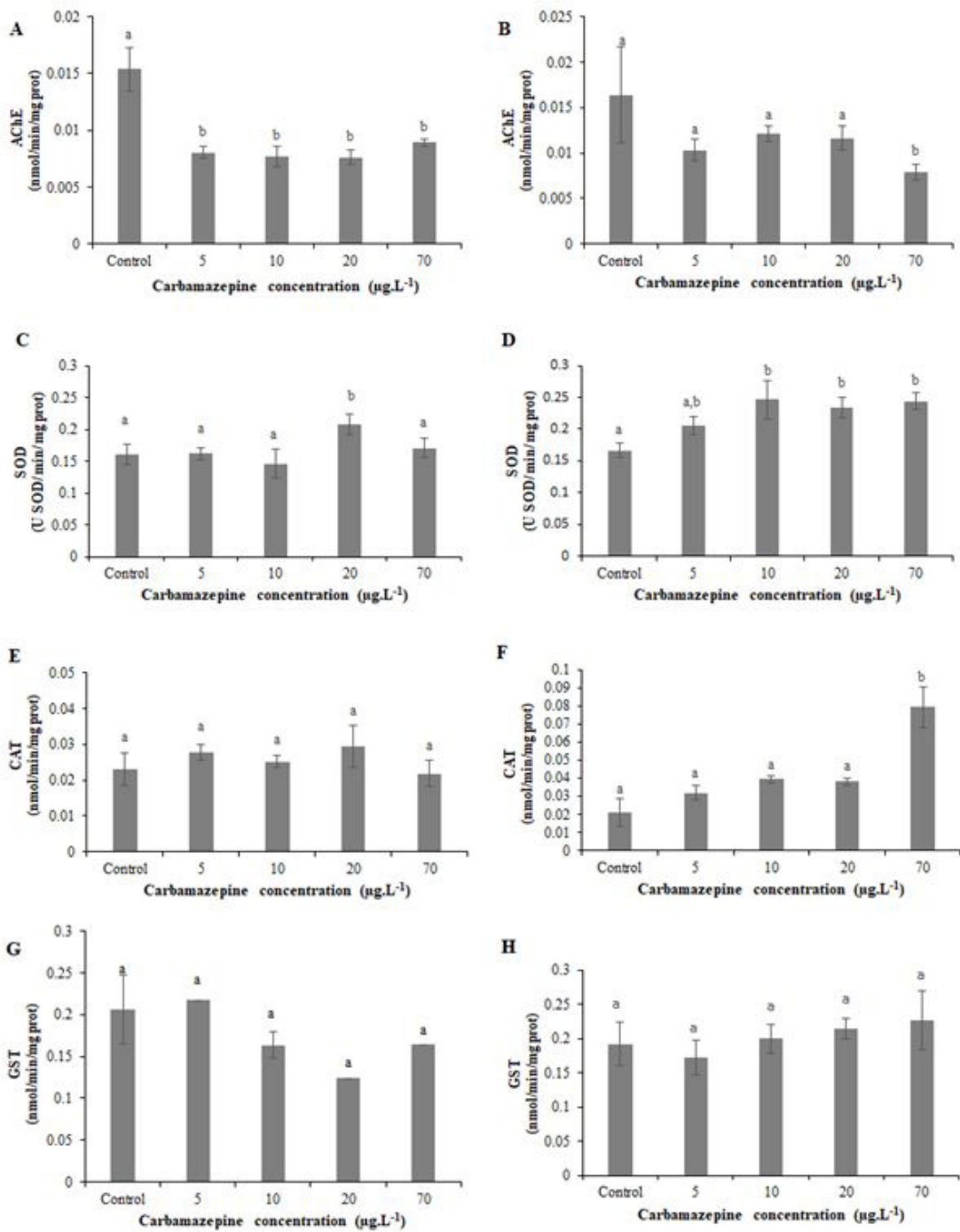

Figure 2. Effect of carbamazepine on enzymatic biomarkers, and AChE activity $48 \mathrm{~h}$ (A), $96 \mathrm{~h}$ (B), Antioxidant enzyme activities, SOD activity $48 \mathrm{~h}(\mathrm{C}), 96 \mathrm{~h}(\mathrm{D})$, CAT activity $48 \mathrm{~h}$ (E), $96 \mathrm{~h}$ (F) and GST activity $48 \mathrm{~h}(\mathrm{G}), 96 \mathrm{~h}(\mathrm{H})$. Values are the mean ( \pm SD) of 5 replicates. Significant differences ( $\mathrm{p} \leq 0.05$ ) among exposure concentrations, for each condition, are presented with different letters (a-b).

woodiana Lea, 1834 (Corsi et al., 2007), the significant decrease of AChE activity observed in the present study (from the lowest treatment concentration $\left(5 \mu \mathrm{g} \mathrm{l}^{-1}\right)$ onwards reinforces a theory that the opening and closing movements of valves may be mediated by cholinergic transmission in cockles. Consequently, following exposure to CBZ, cockle metabolism may slow down, which, in the long term, may be reflected in a reduction in their condition index and general health status (Farcy et al., 2011).

\subsection{Oxidative stress}

Several studies have shown that some contaminants (including pharmaceutical compounds) induce a production of ROS once they penetrate into the organism's tissues (Almeida et al., 2015; Oliveira et al., 2017; Khazri et al., 2018). For this reason, it is of particular interest for environmental biomonitoring programs to follow the response of this type of compound in order to predict contaminant exposure effects.

Living organisms protect their integrity by enzymatic and non-enzymatic antioxidant defense systems. These systems play a detoxifying role for ROS. The majority of pharmaceuticals are designed to be persistent and lipophilic so that they can retain their chemical structure in bodies of aquatic organisms like crustaceans and fish but also after their excretion in the environment for a prolonged period by bioaccumulation and biomagnification throughout the food chain (Martin-Diaz et al., 2009; Aguirre-Martínez et al., 2013; Tsiaka et al., 2013; Chen et al., 2014).

Following the exposure of $C$. edule specimens to $\mathrm{CBZ}$, levels of $\mathrm{H}_{2} \mathrm{O}_{2}$ increased significantly in all exposure treatments after $48 \mathrm{~h}$ and in the highest exposure treatment ( $70 \mu \mathrm{g} \mathrm{l}^{-1}$ ) after $96 \mathrm{~h}$. These high levels of $\mathrm{H}_{2} \mathrm{O}_{2}$ indicate oxidative stress and an overproduction of ROS. SOD activity 

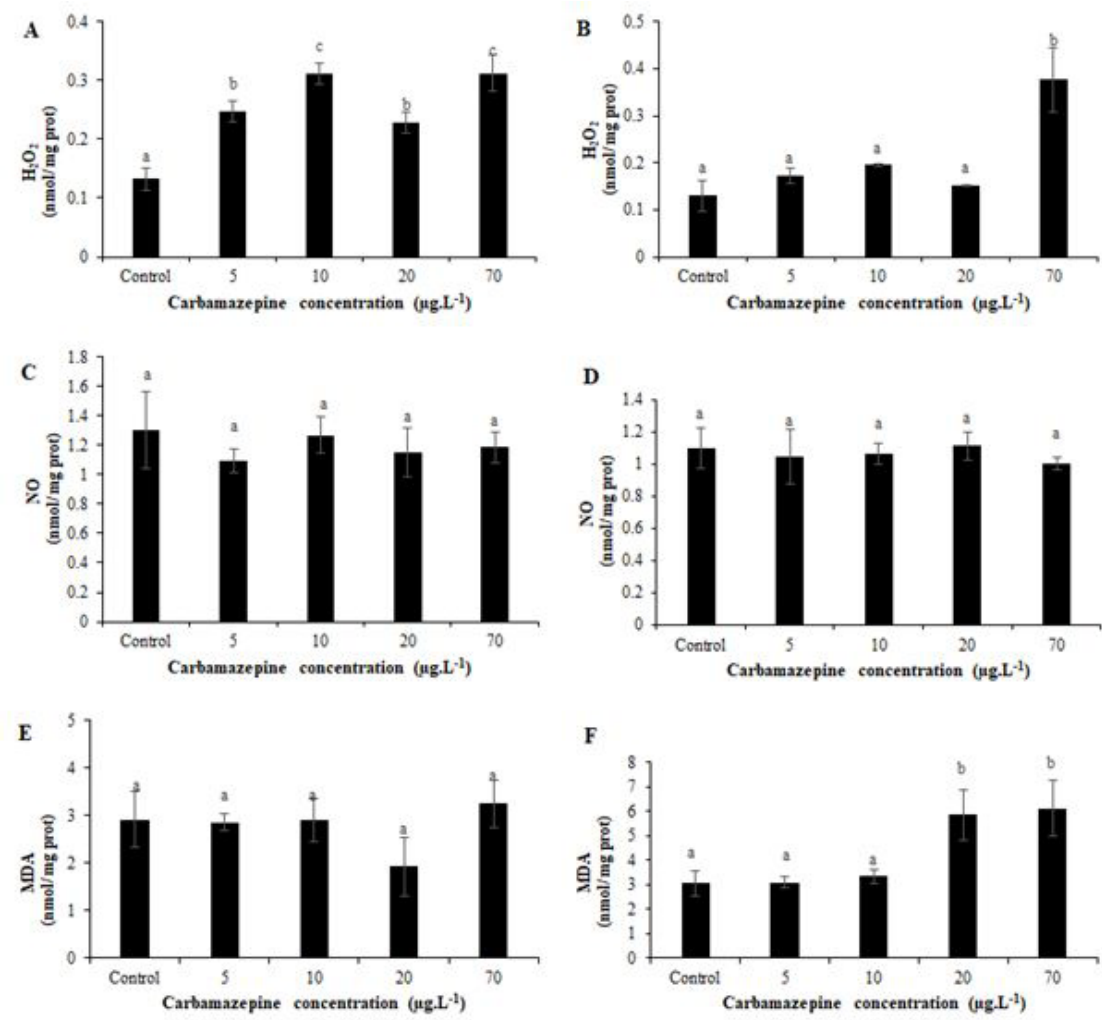

Figure 3. Effect of carbamazepine on proxydants and cellular damage, $\mathrm{H}_{2} \mathrm{O}_{2}$ level $48 \mathrm{~h}$ (A), $96 \mathrm{~h}$ (B), nitrite level NO $48 \mathrm{~h}$ (C), $96 \mathrm{~h}$ (D) and malondialdehyde level MDA $48 \mathrm{~h}(\mathrm{E}), 96 \mathrm{~h}(\mathrm{~F})$. Values are the mean $( \pm$ SD) of 5 replicates. Significant differences $(p \leq 0.05)$ among exposure concentrations, for each condition, are presented with different letters (a-b).

was characterized by a concentration of time-dependent fluctuations following exposure to CBZ. The increase in SOD activity may be explained by an overproduction of the superoxide anion due to the alteration of the oxygen metabolism. The presence of the superoxide anion induces the production of SOD, which then converts it into $\mathrm{H}_{2} \mathrm{O}_{2}$ The observed increase in SOD activity indicates that this enzyme plays an important role in neutralizing the production of ROS. In this context, Almeida et al. (2014, 2015) and Khazri et al. (2018) previously observed an increase in SOD after clam species' $(R$. philippinarum Adams and Reeve, 1850 and $R$. decussatus) exposure to CBZ. However, Li et al. (2009) reported that SOD activity in rainbow trout, Oncorhynchus mykiss, tissues decreased with a CBZ concentration gradient of $0.1,0.2$, and $2 \mathrm{mg} \mathrm{l}^{-1}$ following 21 days of exposure. After prolonged exposure (42 days), a strong inhibition of SOD activity was observed and attributed to the overproduction of ROS and the relatively low activity of the antioxidant system. Similarly, Oliveira et al. (2017) and Freitas et al. (2016) reported decreases in SOD activities in relation to CBZ concentrations in a mussel (M. galloprovincialis) and clam (Scrobicularia plana da Costa, 1778) species following exposure.

CAT activity in organisms is known to be strongly influenced by pharmaceutical exposure (Freitas et al., 2015). Herein, an increase of $\mathrm{H}_{2} \mathrm{O}_{2}$ levels (which induce CAT activity) was induced in specimens from the same exposure treatment $\left(70 \mu \mathrm{g} \mathrm{l}^{-1}\right)$ following $96 \mathrm{~h}$ of exposure. Studies by Almeida et al. (2015) and Martin-Diaz et al. (2009) have shown that CAT activity was not significantly altered following exposure to CBZ in R. philippinarum and M. galloprovincialis mussel species. Almeida et al. (2014) found that the $\mathrm{H}_{2} \mathrm{O}_{2}$ produced by SOD activity was not transformed by CAT but possibly by a GPX enzyme which has similar functions to CAT. In contrast, Chen et al. (2014) noticed opposite results and points of view in the case for specimens belonging to $C$. fluminea after their exposure to 5 and $50 \mu \mathrm{l} \mathrm{l}^{-1} \mathrm{CBZ}$ during one month. Moreover, Li et al. (2011) reported for O. mykiss that CBZ caused after $96 \mathrm{~h}$ an increase in CAT and SOD activities.

The Glutathione-S-Transferase (GST) is a biotransformation enzyme, widely studied in the animal kingdom (Livingstone 1991). Radwan et al. (1992) demonstrated GST activity was induced following exposure of a terrestrial gastropod, Theba pisana Muller, 1774, to carbamates. The authors associated this increase in GST activity with a strong detoxification activity in the body in response to carbamates.

We found no significant variation in GST activity after exposure of $C$. edule to carbamazepine. This suggests that GST activity may only be induced above a certain concentration of CBZ, depending on the species (Oliveira et al., 2017). The absorption of this enzyme is metabolized mainly by cytochrome P450 3A4 isoenzymes (Almeida et al., 
2015). These isoenzymes convert them first into inactive metabolites (10,11-epoxycarbamazepine) and then to excretable metabolites (10,11-dihydroxycarbamazepine). In the present study, there was no significant variation in GST in specimens following 48 and $96 \mathrm{~h}$ of exposure to $\mathrm{CBZ}$, suggesting that $\mathrm{CBZ}$ was not transformed by GST into metabolites. It has also been found that GST isoenzymes oxidize GSH in order to neutralize lipoperoxidation products (Regoli and Giuliani, 2014).

At the highest $\mathrm{CBZ}$ treatment $\left(70 \mu \mathrm{g} \mathrm{l}^{-1}\right)$, MDA levels increased significantly. These results suggest that the production of ROS exceeded their neutralization by antioxidants, thus exhausting the trapping mechanisms and leaving the cellular constituents (lipids and proteins) to be attacked by the overproduction of ROS (Marnett, 1999). Tsiaka et al. (2013) observed an increase in LPO in $M$. galloprovincialis specimens exposed to CBZ (concentrations: $0.01-0 \mathrm{~g} \mathrm{l}^{-1}$ ) for $1 \mathrm{~h}$. In addition, Gagné et al. (2006) found a similar increase in LPO in the hepatocyte of 0 . mykiss following exposure to CBZ for $48 \mathrm{~h}$. An increase of MDA activities was also recorded by Khazri et al. (2018) in the case of $R$. decussatus after its exposure to the CBZ concentrations of 30 and $50 \mu \mathrm{gl}^{-1}$.

Cholinesterases, in particular, $\mathrm{AChE}$, have been found in tissues from our test species, C. edule (Guinot et al., 2012; Nilin et al., 2012). This enzyme is inhibited by several neurotoxicants. AChE activity is considered to be a specific indicator of exposure to environmental contaminants, such as pesticides and hydrocarbons (Day and Scott, 1990; Bocquené and Galgani, 1991; Guilhermino et al., 2000). In the present study, following exposure to $\mathrm{CBZ}$, there was a significant decrease in AChE activity observed in specimens from the lowest concentration treatment $\left(5 \mu \mathrm{g} \mathrm{l}^{-1}\right)$ which could be explained in three ways. First, $\mathrm{H}_{2} \mathrm{O}_{2}$, produced by organisms when their environment is contaminated with CBZ, can be fixed to active sites of AChE (Schallreuter et al., 2004). Second, the CBZ molecule may be attached to this site because its chemical configuration contains nitrile nitrogen. Alternatively, CBZ may decrease the excitability of neurons by stabilizing the inactivated state of voltage-gated sodium channels (Contardo-Jara et al., 2011).

\section{Conclusions}

This study elucidates the acute effects of CBZ, an omnipresent pharmaceutical drug in the aquatic environment, on the cockle $C$. edule. The quantification of CBZ by HPLC-UV proved to be an effective method and gave positive results, not only in the water samples, but also in complex matrices such as $C$. edule tissues. The BCF results show that $\mathrm{CBZ}$ is a bioaccumulative compound.

In relation to physiological parameters, our $C R$ results for C. edule showed a significant decrease in filtration capacity following exposure to CBZ. Even at low concentrations, CBZ induced oxidative stress. Overall, our results highlight the need to improve knowledge on bioaccumulation and the metabolism of pharmaceutical compounds in nontarget organisms in aquatic environments. Moreover, our results suggest a dose-dependent effect. SOD and CAT levels changed according to CBZ treatment concentration, particularly after $98 \mathrm{~h}$ of exposure. Nevertheless, the antioxidant system defenses seemed to be appropriately activated in these conditions. Ultimately, when $C$. edule individuals are exposed to CBZ, they exhibit the signs of cellular damage and an inhibition of acetylcholinesterase activity.

\section{Acknowledgements}

This work was supported by the Tunisian Ministry of the High Education and Scientific Research. The authors extend their appreciation to the deanship of scientific research for funding this article by Taif University Research Supporting Project number (TURSP-2020/119), Taif University, Taif, SAUDI ARABIA.

\section{References}

AEBI, H., 1974. Methods of enzymatic analysis. 2nd ed. New York: Chemia Weinheium.

AGUIRRE-MARTÍNEZ, G.V., BURATTI, S., FABBRI, E., DELVALLS, A.T. and MARTÍN-DÍAZ, M.L., 2013. Using lysosomal membrane stability of haemocytes in Ruditapes philippinarum as a biomarker of cellular stress to assess contamination by caffeine, ibuprofen, carbamazepine and novobiocin. Journal of Environmental Sciences (China), vol. 25, no. 7, pp. 1408-1418. http://dx.doi.org/10.1016/ S1001-0742(12)60207-1.

ALMEIDA, Â., CALISTO, V., ESTEVES, V.I., SCHNEIDER, R.J., SOARES, A.M.V.M., FIGUEIRA, E. and FREITAS, R., 2014. Presence of the pharmaceutical drug carbamazepine in coastal systems: effects on bivalves. Aquatic Toxicology (Amsterdam, Netherlands), vol. 156, pp. 74-87. http://dx.doi.org/10.1016/j.aquatox.2014.08.002.

ALMEIDA, A., FREITAS, R., CALISTO, V., ESTEVES, V.J., SCHNEIDER, R., SOARES, A. and FIGUEIRA, E., 2015. Chronic toxicity of the antiepileptic carbamazepine on the clam Ruditapes philippinarum. Comparative Biochemistry and Physiology, vol. 172-173, pp. 26-35.

BOCQUENÉ, G. and GALGANI, F., 1991. Acetylcholinesterase activity in the common prawn Palaemon serratus contaminated by carbaryl and phosalone. Ecotoxicology and Environmental Safety, vol. 22, no. 3, pp. 337-345. http://dx.doi.org/10.1016/01476513(91)90083-2.

BRADFORD, M.M., 1976. A rapid and sensitive method for the quantization of microgram quantities of protein utilizing the principle of protein-dry binding. Analytical Biochemistry, vol. 72, no. 1-2, pp. 248-254. http://dx.doi.org/10.1016/00032697(76)90527-3.

CHEN, H., ZHA, J., LIANG, X., LI, J. and WANG, Z., 2014. Effects of the human antiepileptic drug carbamazepine on the behavior, biomarkers, and heat shock proteins in the Asian clam Corbicula fluminea. Aquatic Toxicology (Amsterdam, Netherlands), vol. 155, pp. 1-8. http://dx.doi.org/10.1016/j.aquatox.2014.06.001.

CLARA, M., STRENN, B. and KREUZINGER, N., 2004. Carbamazepine as a possible anthropogenic marker in the aquatic environment: investigations on the behavior of carbamazepine in wastewater treatment and during groundwater infiltration. Water Research, vol. 38, no. 4, pp. 947-954. http://dx.doi.org/10.1016/j. watres.2003.10.058.

CONTARDO-JARA, V., LORENZ, C., PFLUGMACHER, S., NUTZMANN, G., KLOAS, W. and WIEGAND, C., 2011. Exposure to human pharmaceuticals carbamazepine, ibuprofen and bezafibrate 
causes molecular effects in Dreissena polymorpha. Aquatic Toxicology (Amsterdam, Netherlands), vol. 105, no. 3-4, pp. 428437. http://dx.doi.org/10.1016/j.aquatox.2011.07.017.

CORSI, I., PASTORE, A.M., LODDE, A., PALMERINI, E., CASTAGNOLO, L. and FOCARDI, S., 2007. Potential role of cholines terases in the invasive capacity of the freshwater bivalve, Anodonta woodiana (Bivalvia: Unionacea): a comparative study with the indigenous species of the genus, Anodonta sp. Comparative Biochemistry and Physiology, vol. 145, no. 3, pp. 413-419.

COUGHLAN, J., 1969. The estimation of filtering rate from the clearance of suspensions. Marine Biology, vol. 2, no. 4, pp. 356-358. http://dx.doi.org/10.1007/BF00355716.

DAY, K.E. and SCOTT, I.M., 1990. Use of Acetylcholinesterase activity to detect sublethal toxicity in stream in vertebrates exposed to low concentrations of organophosphorate insecticides. Aquatic Toxicology (Amsterdam, Netherlands), vol. 18, no. 2, pp. 101-114. http://dx.doi.org/10.1016/0166-445X(90)90021-G.

DE MONTAUDOUIN, X., PAUL-PONT, I., LAMBERT, C., GONZALEZ, P., RAYMOND, N., JUDE, F., LEGEAY, A., BAUDRIMONT, M., DANG, C., LE GRAND, F., LE GOÏC, N., BOURASSEAU, L. and PAILLARD, C., 2010. Bivalve population health: multistress to identify hot spots. Marine Pollution Bulletin, vol. 60, no. 8, pp. 1307-1318. http://dx.doi.org/10.1016/j.marpolbul.2010.03.011.

DELLALI, M., GNASSIA BARELLI, M., ROMEO, M. and AISSA, P., 2001. The use of acetylcholinesterase activity in Ruditapes decussatus and Mytilus galloprovincialis in the biomonitoring of Bizerta lagoon. Comparative Biochemistry and Physiology. Toxicology $\mathcal{E}$ Pharmacology : CBP, vol. 130, no. 2, pp. 227-235. http://dx.doi. org/10.1016/S1532-0456(01)00245-9 PMid:11574292.

DRAPER, H.H. and HADLEY, M., 1990. Malondialdehyde determination as index of lipid peroxidation. Methods in Enzymology, vol. 186, pp. 421-431. http://dx.doi.org/10.1016/0076-6879(90)86135-I.

ELLMAN, G.L., COURTNEY, K.D., ANDRES JUNIOR, V. and FEATHERSTONE, R.M., 1961. A new and rapid colorimetric determination of acetylcholinesterase activity. Biochemical Pharmacology, vol. 7, no. 2, pp. 88-95. http://dx.doi. org/10.1016/0006-2952(61)90145-9.

FARCY, E., GAGNE, F., MARTEL, L., FORTIER, M., TRÉPANIER, S., BROUSSEAU, P. and FOURNIER, M., 2011. TREPANIER.S., BROUSSEAU, P., and FOURNIER, M., 2011. Short-term physiological effects of a xenobiotic mixture on the freshwater mussel Elliptio complanata exposed to municipal effluents. Environmental Research, vol. 111, no. 8, pp. 1096-1106. http:// dx.doi.org/10.1016/j.envres.2011.07.009.

FREITAS, R., ALMEIDA, A., CALISTO, V., VELEZ, C., MOREIRA, A., SCHNEIDER, R.J., ESTEVES, I., WRONA, F.J., SOARES, A.M. and FIGUEIRA, E., 2016. How life history influences the responses of the clam Scrobicularia plana to the combined impacts of carbamazepine and pH decrease. Environmental Pollution, vol. 202, pp. 205-214. http://dx.doi.org/10.1016/j.envpol.2015.03.023.

FREITAS, R., ALMEIDA, A., PIRES, A., VELEZ, C., CALISTO, V., SCHNEIDER, R.J., ESTEVES, V.I., WRONA, F.J., FIGUEIRA, E. and SOARES, A.M.V.M., 2015. The effects of carbamazepine on macro invertebrate species: comparing bivalves and polychaetes biochemical responses. Water Research, vol. 85, pp. 137-147. http://dx.doi.org/10.1016/j.watres.2015.08.003.

GAGNÉ, F., BLAISE, C. and ANDRÉ, C., 2006. Occurrence of pharmaceutical products in a municipal effluent and toxicity to rainbow trout (Oncorhynchus mykiss) hepato-cytes. Ecotoxicology and Environmental Safety, vol. 64, no. 3, pp. 329-336. http:// dx.doi.org/10.1016/j.ecoenv.2005.04.004
GOSLING, E., 2003. Morphology of bivalves. In: E. Gosling, ed. Bivalve molluscs, biology, ecology and culture. Oxford: Fishing News Books, pp. 7-43.

GREEN, L.C., WAGNER, D.A., GLOGOWSKI, J., SKIPPER, P.L., WISHNOK, J.S. and TANNENBAUM, S.R., 1982. Analysis of nitrate, nitrite, and $[15 \mathrm{~N}]$ nitrate in biological fluids. Analytical Biochemistry, vol. 126, no. 1, pp. 131-138. http://dx.doi.org/10.1016/00032697(82)90118-X.

GUASMI, I., DJABRI, L., HANI, A. and LAMOUREUX, C., 2006. Pollution des eaux de l'oued medjerda par les nutriments. Larhyss Journal, vol. 5, pp. 113-119.

GUILHERMINO, L., LACERDA, M.N., NOGUEIRA, A.J.A. and SOARES, A.M.V.M., 2000. In vitro and in vivo inhibition of Daphnia magna acetylcholinesterase by surfactant agents: possible implications for contamination biomonitoring. The Science of the Total Environment, vol. 247, no. 2-3, pp. 137-141. http:// dx.doi.org/10.1016/S0048-9697(99)00485-4.

GUINOT, D., UREÑA, R., PASTOR, A., VARO, I., RAMO, J. and TORREBLANCA, A., 2012. Long-term effect of temperature on bioaccumulation of dietary metals and metallothionein induction in Sparus aurata. Chemosphere, vol. 87, no. 11, pp. 1215-1221. http://dx.doi.org/10.1016/j.chemosphere.2012.01.020.

HABIG, W.H., PABST, M.J. and JAKOBY, W.B., 1974. Glutathione $\mathrm{S}$-transferases. The first enzymatic step in mercapturic acid formation. The Journal of Biological Chemistry, vol. 249, no. 22, pp. 7130-7139. http://dx.doi.org/10.1016/S0021-9258(19)42083-8.

HUERTA-FONTELA, M., GALCERAN, M.T. and VENTURA, F., 2011. Occurrence and removal of pharmaceuticals and hormones through drinking water treatment. Water Research, vol. 45, no. 3, pp. 1432-1442. http://dx.doi.org/10.1016/j.watres.2010.10.036.

KAKINUMA, K., YAMAGUCHI, T., KANEDA, M., SHIMADA, K., TOMITA, Y. and CHANCE, B., 1979. Determination of $\mathrm{H}_{2} \mathrm{O}_{2}$ release by the treatment of human blood polymorphonuclear leucocytes with myristate. Journal of Biochemistry, vol. 86, pp. 87-95.

KHAZRI, A., MEZNI, A., KHAZRI, H., SELLAMI, B., ACENA, J., PEREZ, S., ELJARRAT, E., BARCELÓ, D., BEYREM, H. and MAHMOUDI, E., 2018. Uptake and metabolism of Carbamazepine (CBZ) by Clam Ruditapes decussatus and its effects in biochemical responses. Xenobiotica, vol. 48, no. 7, pp. 727-733. http://dx.doi.org/10.1 080/00498254.2017.1354268.

KHAZRI, A., SELLAMI, B., DELLALI, M., CORCELLAS, C., ELJARRAT, E., BARCELO, D., BEYREM, H. and MAHMOUDI, E., 2016. Diastereomeric and enantiomeric selective accumulation of cypermethrin in the freshwater mussel Unio gibbus and its effects on biochemical parameters. Pesticide Biochemistry and Physiology, vol. 129, pp. 83-88. http://dx.doi.org/10.1016/j. pestbp.2015.11.001.

KHAZRI, A., SELLAMI, B., HANACHI, A., DELLALI, M., ELJARRAT, E., BEYREM, H. and MAHMOUDI, E., 2017. Neurotoxicity and oxidative stress induced by permethrin in gills of the freshwater mussel Unio ravoisieri. Chemistry and Ecology, vol. 33, no. 1, pp. 88-101. http://dx.doi.org/10.1080/02757540.2016.1248948.

KHAZRI, H., BEN HASSINE, S., GHORBEL-ABID, I., KALFAT, R. and TRABELSI-AYADI, M., 2019a. Presence of carbamazepine, naproxen, and ibuprofen in wastewater from northern Tunisia. Environmental Forensics, vol. 20, no. 2, pp. 121-128. http:// dx.doi.org/10.1080/15275922.2019.1597779.

KHAZRI, H., GHORBEL-ABID, I., DEBRAUWER, L., KALFAT, R. and TRABELSI-AYADI, M., 2019b. Solid-phase extraction of drugs with cuttlebone powder as a sorbent. Journal of Separation Science, vol. 41, no. 18, pp. 3547-3552. http://dx.doi.org/10.1002/ jssc.201800419. 
LI, Z.H., ZLABEK, V., VELISEK, J., GRABIC, R., MACHOVA, J. and RANDAK, T., 2009. Responses of antioxidant status and $\mathrm{Na}+/ \mathrm{K}+-$ ATPase activity in gill of rainbow trout, Oncorhynchus mykiss, chronically treated with carbamazepine. Chemosphere, vol. 77, no. 11, pp. 1476-1481. http://dx.doi.org/10.1016/j.chemosphere.2009.10.031.

LI, Z.H., ZLABEK, V., VELISEK, J., GRABIC, R., MACHOVA, J., KOLAROVA, J., LI, P. and RANDAK, T., 2011. Acute toxicity of carbamazepine to juvenile rainbow trout (Oncorhynchus mykiss): effects on antioxidant responses, hematological parameters and hepatic EROD. Ecotoxicology and Environmental Safety, vol. 74, no. 3, pp. 319-327. http://dx.doi.org/10.1016/j.ecoenv.2010.09.008.

LIU, J., LU, G., XIE, Z., ZHANG, Z., LI, S. and YAN, Z., 2015. Occurrence, bioaccumulation and risk assessment of lipophilic pharmaceutically active compounds in the downstream rivers of sewage treatment plants. The Science of the Total Environment, vol. 511, pp. 54-62. http://dx.doi.org/10.1016/j. scitotenv.2014.12.033.

LIVINGSTONE, D.R., 1991. Organic xenobiotic metabolism in marine invertebrates. Advances in Comparative and Environmental Physiology, vol. 7, pp. 46-185.

MAHMOUDI, E., HAMOUDA, B. and AÏSSA, P., 2002. Réponse des nématodes libres à la qualité des eaux et des sédiments de la lagune de Ghar El Melh Tunisie en été 1999. Cahiers de Biologie Marine, vol. 43, pp. 83-93.

MARNETT, L.J., 1999. Oxyradicals and DNA damage. Carcinogenesis, vol. 21, no. 3, pp. 361-370. http://dx.doi.org/10.1093/ carcin/21.3.361.

MARTIN-DIAZ, L., FRANZELLITTI, S., BURATTI, S., VALBONESI, P., CAPUZZO, A. and FABBRI, E., 2009. Effects of environmental concentrations of the antiepileptic drug carbamazepine on biomarkers and cAMP-mediated cell signaling in the mussel Mytilus Galloprovincialis. Aquatic Toxicology (Amsterdam, Netherlands), vol. 94, no. 3, pp. 177-185. http://dx.doi. org/10.1016/j.aquatox.2009.06.015.

MISRA, H.P. and FRIDOVICH, I., 1972. The role of superoxide dismutase anion in the auto-oxidation of epinephrine and a simple assay for superoxide dismutase. Journal of Biochemistry, vol. 247, pp. 3170-3175.

NILIN, J., MONTEIRO, M., DOMINGUES, I., LOUREIRO, S., COSTALOTUFO, L.V. and SOARES, A., 2012. Bivalve Esterases as Biomarker: Identification and Characterization in European Cockles (Cerastoderma edule). Bulletin of Environmental Contamination and Toxicology, vol. 88, no. 5, pp. 707-711. http:// dx.doi.org/10.1007/s00128-012-0521-2.

NOGUERA-OVIEDO, K. and AGA, D.S., 2016. Lessons learned from more than two decades of research on emerging contaminants in the environment. Journal of Hazardous Materials, vol. 316 , pp. 242-251. http://dx.doi.org/10.1016/j.jhazmat.2016.04.058.

OLIVEIRA, P., ALMEIDA, A., CALISTO, V., ESTEVES, V.I., SCHNEIDER, R.J., WRONA, F.J., SOARES, A.M., FIGUEIRA, E. and FREITAS, R., 2017. Physiological and biochemical alterations induced in the mussel after short and long-term exposure Mytilus galloprovincialis to carbamazepine. Water Research, vol. 117, pp. 102-114. http://dx.doi.org/10.1016/j.watres.2017.03.052.
PAUL-PONT, I., GONZALEZ, P., BAUDRIMONT, M., JUDE, F., RAYMOND, N., BOURRASSEAU, L., LE GOÏC, N., HAYNES, F., LEGEAY, A., PAILLARD, C. and DE MONTAUDOUIN, X., 2010. Interactive effects of metal contamination and pathogenic organisms on the marine bivalve Cerastoderma edule. Marine Pollution Bulletin, vol. 60, no. 4, pp. 515-525. http://dx.doi.org/10.1016/j. marpolbul.2009.11.013.

RADWAN, M.A., EL-WAKIL, H.B. and OSMAN, K.A., 1992. Toxicity and biochemical impact of certain oxime carbamate pesticides against terrestrials nail, Theba pisana (Muller). Journal of Environmental Science and Health, vol. 27, no. 6, pp. 759-773. http://dx.doi.org/10.1080/03601239209372811.

REGOLI, F. and GIULIANI, M.E., 2014. Oxidative pathways of chemical toxicity and oxidative stress biomarkers in marine organisms. Marine Environmental Research, vol. 93, pp. 106-117. http:// dx.doi.org/10.1016/j.marenvres.2013.07.006.

SALHI, N., ZMERLI TRIKI, H., MOLINERO, J.C., LAABIR, M., SEHLI, E., BELLAAJ-ZOUARI, A., DALY YAHIA, N. and KEFI-DALY YAHIA, O., 2018. Seasonal variability of picophytoplankton under contrasting environments in northern Tunisian coasts, southwestern Mediterranean Sea. Marine Pollution Bulletin, vol. 129, no. 2, pp. 866-874. http://dx.doi.org/10.1016/j. marpolbul.2017.10.029.

SANTOS, L.H., ARAÚJO, A.N., FACHINI, A., PENA, A., DELERUE-MATOS, C. and MONTENEGRO, M.C., 2010. Ecotoxicological aspects related to the presence of pharmaceuticals in the aquatic environment. Journal of Hazardous Materials, vol. 175, no. 1-3, pp. 45-95. http://dx.doi.org/10.1016/j.jhazmat.2009.10.100.

SCHALLREUTER, K.U., ELWARY, S.M., GIBBONS, N.C., ROKOS, H. and WOOD, J.M., 2004. Activation/deactivation of acetylcholinesterase by $\mathrm{H}_{2} \mathrm{O}_{2}$ : more evidence for oxidative stress in vitiligo. Biochemical and Biophysical Research Communications, vol. 315, no. 2, pp. 502-508. http://dx.doi.org/10.1016/j. bbrc.2004.01.082.

SELLAMI, B., MEZNI, A., KHAZRI, A., BOUZIDI, I., SAIDANI, W., SHEEHAN, D. and BEYREM, H., 2017. Toxicity assessment of $\mathrm{ZnO}$-decorated Au nanoparticles in the Mediterranean clam Ruditapes decussatus. Aquatic Toxicology (Amsterdam, Netherlands), vol. 188, pp. 10-19. http://dx.doi.org/10.1016/j. aquatox.2017.04.005.

SUI, Q., CAO, X., LU, S., ZHAO, W., QIU, Z. and YU, G., 2015. Occurrence, sources and fate of pharmaceuticals and personal care products in the groundwater: a review. Emerging Contaminants, vol. 1, no. 1, pp. 14-24. http://dx.doi.org/10.1016/j.emcon.2015.07.001.

TSIAKA, P., TSARPALI, V., NTAIKOU, I., KOSTOPOULOU, M.N., LYBERATOS, G. and DAILIANIS, S., 2013. Carbamazepinemediated pro-oxidant effects on the unicellular marine algal species Dunaliella tertiolecta and the hemocytes of mussel Mytilus galloprovincialis. Ecotoxicology (London, England), vol. 22, no. 8, pp. 1208-1220. http://dx.doi.org/10.1007/s10646-013-1108-3.

ZHANG, X., YANG, F., ZHANG, X., XU, Y., LIAO, T., SONG, S. and WANG, H., 2008. Induction of hepatic enzymes and oxidative stress in Chinese rare minnow (Gobiocypris rarus) exposed to waterborne hexabromocyclododecane (HBCDD). Aquatic Toxicology (Amsterdam, Netherlands), vol. 86, no. 1, pp. 4-11. http://dx.doi.org/10.1016/j.aquatox.2007.07.002. 